\title{
Personal Relations and their Effect on Behavior in an Organizational Setting: An Experimental Study
}

\author{
December 2006
}

Jordi Brandts and Carles Solà

\begin{abstract}
We study how personal relations affect performance in organizations. In the experimental game we use a manager has to assign different degrees of decision power to two employees. These two employees then have to make distributive decisions which affect themselves and the manager. Our focus is on the effects on managers' assignment of decision power and on employees' distributive decisions of one of the employees and the manager knowing each other personally. Our evidence shows that managers tend to favor employees that they personally know and that these employees tend, more than other employees, to favor the manager in their distributive decisions. However, this behavior does not affect the performance of the employees that do not know the manager. All these effects are independent of whether the employees that know the manager are more or less productive than those who do not know the manager. The results shed light on discrimination and nepotism and its consequences for the performance of family firms and other organizations.
\end{abstract}

\section{Keywords}

Family firms, nepotism, corporate governance, procedural fairness, experiments

JEL Classification Codes: C92, D23, M50

\section{Acknowledgements}

Financial support from Spanish Ministerio de Educación, Ciencia y Deporte (SEJ2005-01690 and SEJ-200407530-C04), the Barcelona Economics programme CREA, and the Catedra Banca March de l'Empresa Familiar is greatfully acknowledged. The paper has benefitted from presentations at the ESA Asian regional meeting in Hong-Kong and the ESA international meeting in Atlanta, both in 2006. The authors thank David Rodríguez and Javier Valbuena for help in running the experiments.

Author addresses

\begin{tabular}{ll}
\hline \multicolumn{1}{c}{ Jordi Brandts } & \multicolumn{1}{c}{ Carles Solà } \\
\hline $\begin{array}{l}\text { Institut d’Anàlisi Econòmica (CSIC) } \\
\text { Campus UAB }\end{array}$ & Universitat de les Illes Balears \\
$\begin{array}{l}\text { C8193 Bellaterra } \\
\text { Spain }\end{array}$ & $\begin{array}{l}\text { Campus UIB, Departament Economia de l’Empresa } \\
\text { Spain }\end{array}$ \\
& \\
Phone+34-935806612 & Phone: +34-971172438 \\
$\begin{array}{l}\text { Fax+34-935801452 } \\
\text { Jordi.Brandts@uab.es }\end{array}$ & Fax: +34-971172389 \\
\hline
\end{tabular}




\section{Introduction}

We present data from experiments in which we study whether people favor their friends in a stylized organizational setting and whether this has any effect on the behavior of other people involved in the situation. The principal motivation for our study stems from the debate on discrimination and favoritism and the assignment of responsibilities in family firms, but our work can also be related to other organizational forms. Economists have recently been devoting considerable attention to the study of family firms, a form of corporate governance which has a sizeable weight in most economies (see La Porta, Lopez de Salinas, and Shleifer, 1999). In the work presented here we use experiments to shed some light on some of the issues that up to now have been studied using exclusively field data.

A number of previous field data studies focus directly on differences in performance between family firms and non-family firms. Perhaps surprisingly the empirical evidence is, at this point, mixed. Several papers support the transaction cost hypothesis (Pollak, 1985) of no difference in performance, for example Cho (1998), or Demsetz and Villalonga (2001). However, there is also evidence of both more (Villalonga and Amit, 2004 and Morck, Shleifer and Vishny, 1998), and of less economic value being created under family firm governance (McConaughy et al., 1998 and Anderson and Reeb, 2003).

Other studies aim at identifying more specific differences between family and non-family firms. One of these differences pertains to issues of equity, distributive justice and procedural justice. Greenberg (1990) surveys research on how different justice notions interact with interpersonal effects. Van der Hayden et al. (2005) analyze these ideas in the specific context of family firms, where personal relations play a key role in certain decisions, and refer to the different concepts of distributive justice that 
play a key role in family firms. Families use need-based justice among its members, managers use meritocracy and shareholders use equality. Distributive justice, hence, may be difficult to implement in family firms due to the different criteria used between agents.

From a different perspective, Schulze et al. (2001), Burkart et al. (2003), or Mork et al. (2004) study how the agency problem (Jensen \& Meckling, 1976) is modified in family firms. A common theme of these studies is the altruism of the owner towards the heir and the possible effects that this attitude may have in alleviating or worsening the agency problems. This has been analyzed from a theoretical point of view by Chami (2001) and Burkart et al. (2003). Nepotism, defined as favoritism shown or patronage granted to relatives, is one possible consequence of this altruism. Similar problems may arise in relation to personal friends.

The consequences of nepotism are somewhat controversial. Fama and Jensen (1983) consider that family relationships between owners and managers reduce the agency problem. Kang (2000) argues that family-related managers have a deep knowledge of the firm that allows them to evaluate risks more adequately and to make better strategic decisions. Miller and Le Breton-Miller (2006) discuss the possible positive effects of choosing a family member as a top executive due to higher motivation - in the line of stewardship theory.

Other analysts provide arguments and evidence in favor of the effects of nepotism in family firms being negative. Pérez-Gonzalez (forthcoming) analyzes CEO successions in family firms using data from 335 management transitions in publicly traded U.S. corporations with concentrated ownership of founding family involvement. He finds that promotion of CEOs with family ties is indeed frequent. Family CEOs attain this position earlier than non family CEOs - on average eight years earlier. This 
kind of pro-family bias leads to considerable declines in performance, as measured by returns on assets and market-to-book ratios. Moreover, this effect is greater when the family CEO has not attended a selected business school (a signal of good quality); interestingly, this school quality effect is not observed in non-family CEO promotions. In the same line Kets de Vries (1993) points to the tolerance of inept family members as managers. Schulze et al. (2001) indicate that nepotism may also affect other decisions besides CEO succession: promotion to selected places in the organization, better remunerations or more training. Kole (1997) and Bates, Jandik and Lehn (1998) find evidence of theses practices.

We will refer to this bias based on family or personal relations that may result in the choice of suboptimal managers and to the possible reactions of favored individuals as the direct effects of nepotism. However, this may not be all that needs to be considered. Nepotism may also have an indirect effect. If a decision based on family relations or friendship violates economic or fairness principles, other agents in the organization may feel discriminated since they do not benefit from the decision only because they do not belong to the insider group. Hence, they may perceive that their earnings, positions, status or job security levels are below what they deserve in comparison to the insiders. If this perception arises, negative reactions from these agents may result. This indirect effect in family firms is discussed in Schulze et al (2001) and Gomez-Mejia et al. (2001).

Schulze et al. (2001) argue that agency threats of family ownership come partially from adverse selection and hold up in non-family top management (also see Kets de Vries, 1993). Gomez-Mejia et al. (2001) claim that these effects may go beyond top management to middle management, and may generate shirking behavior. They consider that "lower-level managers may resent the implicit immunity top-level 
executives gain from their family status rather than from demonstrated performance” (Gomez-Mejia et al., 2001). Hence, the conflict between meritocracy and nepotism may produce unsatisfied workers, who are less motivated to work hard. Miller and Le Breton-Miller (2006) point out that a bias in favor of family candidates risks alienating other talented managers.

In this paper we use a simple experimental design to study if, in the presence of personal relations between agents, discrimination occurs and whether it leads to poor results. The essence of what goes on in the organizational settings we are interested in can be captured in a situation in which a decision-maker or manager has to assign certain unequal degrees of responsibility or decision power to two different subordinates or employees; one of the employees will obtain discretionary power over a larger part of a pie than the other. These two employees then have to make distributive decisions which affect themselves and the manager.

We study the impact of two treatment variables. The first is the existence of a personal connection between the manager and one of the employees; we compare the cases where this connection exists and where it does not exist. The other treatment variable is the ratio of productivities of the two employees. In the base case the two employees have the same productivity, whereas in the two other cases we look at the productivities are different. The resulting design with six treatments makes it possible to study the effect of a personal connection between the manager and one of the employees for the cases where the employee in question is equally, more or less productive than the other employee.

There are a good number of experiments on organizational behavior issues, reflecting the fact that many interesting issues in the area can be nicely studied in the kinds of stylized environments commonly used in experimental work. Some recent 
experimental studies in the area are those of Weber et al. (2001) and Malhotra and Murnighan (2002) and Malhotra (2004). One of the things this kind of work has in common with ours is that it studies interrelations between the effects of given material (extrinsic) incentives and other motivational influences.

Our research is also related to the literature on social preferences. We will be studying an environment in which a person will make a transfer to other persons hoping to get something back. The fact that the other players often do return something can be explained by notions of reciprocity (Sugden, 1984), fairness (Rabin, 1993) or inequality aversion (Bolton and Ockenfels, 2000 and Fehr and Schmidt, 1999). These models and the experiments directly related to them did not take into account the fact that many interactions take place between people that know each other personally. However, there are some experimental papers which do take into account interpersonal effects like the ones we study here. An important general notion in this context is 'social distance' as discussed in Akerloff (1997) and Hoffman et al. (1996). Bohnet and Frey (1999) show that dictator game giving is affected by whether the dictator can simply visually identify the recipient and by whether the recipient can identify the dictator. This is consistent with the notion that letting subjects see each other, identify each other by names, etc. reduces social distance For our purposes we needed preexistent social relations, a situation with even less social distance.

Our treatment configuration makes it possible to study both the direct and indirect effects of nepotism. In designing the experiment we have aimed at finding an unbiased environment, which a priori does not seem to be specially favorable neither to the existence nor the absence of the two effects of nepotism. Our objective was to let the data speak for themselves. 
We find evidence for the direct nepotism effect in that managers tend to favor employees that they personally know and that these employees tend, more than other employees, to favor the manager in their distributive decisions. However, nepotism does not affect the performance of the employees that do not know the manager. All these effects are independent of whether the employees that know the manager are more or less productive than the employees who do not know the manager. We also find that the joint performance of employees is significantly higher in the presence of personal relations, regardless of productivity differences.

\section{Design and Hypotheses}

In our game Player $A$ is given a fixed amount of $10 €$ that has to be passed on to Player B and Player C in fixed proportions. The choice that $\mathrm{A}$ has is to give $6 €$ to $\mathrm{B}$ and $4 €$ to $\mathrm{C}$ or vice versa. ${ }^{1}$ Player $\mathrm{A}$ can be seen as representing the manager of a firm or organization who has to assign different levels of responsibility or decision power represented by the different shares of the initial pie - to two of her employees, B and C.

Once Player A has decided how to assign the two shares, the amount sent to player $B$ is multiplied by a factor $M_{B}$ and the amount received by player $C$ is multiplied by $M_{C}$. These factors represent the productivities of the two agents or employees. The introduction of these factors allows us to distinguish between responsibility and productivity levels. While the shares the employees are assigned by the manager can be seen as the responsibility levels, the multiplicative factors can be naturally interpreted as the productivities of the two employees. This distinction is important for our analysis below.

1 The game we use is similar to the game of Brandts et al. (2006) and is also related to the well-known trust game (Berg et. al., 1995). This kind of games have been used to represent organizational environments like the one we study here. 
Our design incorporates two treatment variables. The first of them pertains to whether the principal personally knows one of the agents or not. In our anonymous treatments the game was played in the standard fashion: subjects did not know who the others in the trio were. In our friends treatments Player A and Player B knew each other personally, but both did not know Player C personally. In turn, Player C did not know either Player A or Player B, but did know that Players A and B knew each other personally. ${ }^{2}$

Apart from varying whether A and B know each other or not, we also vary the factors $M_{B}$ and $M_{C}$. We study 3 different productivity pairs. The first is the case of equal productivities, $\mathrm{M}_{\mathrm{B}}=\mathrm{M}_{\mathrm{C}}=3$. The pies that - after the multiplication - the two employees have to distribute will be of sizes $18 €$ and $12 €$. In the second configuration of productivities, player B is a low productivity employee (hereafter we will refer to this case as $B$ Low) and the two productivities are $\mathrm{M}_{\mathrm{B}}=2.5$ and $\mathrm{M}_{\mathrm{C}}=3.75$. In the third case $\mathrm{B}$ is a high productivity agent (hereafter, $B$ High): $\mathrm{M}_{\mathrm{B}}=3.5$ and $\mathrm{M}_{\mathrm{C}}=2.25$. $^{3}$

The numbers for the B Low and B High cases were selected in a way that keeps the total pie size equal to the one in the baseline case of equal productivities at $30 €$ for the case in which B obtains the larger share. ${ }^{4}$ Given this restriction B and C players can not simply exchange the productivities between the two unequal productivities treatments. The chosen productivities satisfy the restriction given by the baseline; in addition we tried to keep the ratio of productivities as close as possible to the ratio of shares. The ration of shares is 1.5 , since (High Share)/(Low share) $=6 / 4$, while the ratio of productivities is $\mathrm{M}_{\mathrm{B}} / \mathrm{M}_{\mathrm{C}}=3.5 / 2.25=1.55$ for the $\mathrm{B}$ High case, and $\mathrm{M}_{\mathrm{C}} / \mathrm{M}_{\mathrm{B}}=3.75 / 2.25=1.5$ for the B Low case. However, remember that the comparisons 
that we are mainly interested in are the ones corresponding to the friends vs. anonymous distinction, so that the above choice of parameters is not crucial.

Once players B and C have been informed about the amount received they have to decide simultaneously and without any communication how much of the pie they control they want to give (back) to Player $\mathrm{A}$; we call these amounts $\mathrm{x}_{\mathrm{B}}$ and $\mathrm{x}_{\mathrm{C}}$. The payoff for player A is the sum of the amount sent by players B and C. Players B and C get, respectively, what they decide to keep for themselves. The straightforward game theoretical prediction in this game - if players' utility functions just incorporate their own payoff, the game is played only once and players do not know each other - is that both Player B and Player C will give nothing to Player A. Player A is, hence, indifferent with respect to how to distribute the initial pie between Player B and Player C.

Table 1 presents a summary of our treatments. In total we have six different cases which arise from the three different productivity configurations of Player B and C and the existence or absence of personal relations between player A and Player B. Table 1 also introduces the acronyms for the different treatments which we will use below.

\section{Table 1. Summary of Treatments}

\begin{tabular}{|c|c|c|c|c|}
\hline & & \multicolumn{3}{|c|}{ PRODUCTIVITIES } \\
\hline & & $\begin{array}{c}\text { Equal Prod. } \\
\qquad \mathrm{M}_{\mathrm{B}}=\mathrm{M}_{\mathrm{C}}\end{array}$ & $\begin{array}{c}\text { B Low } \\
\mathrm{M}_{\mathrm{B}}<\mathrm{M}_{\mathrm{C}}\end{array}$ & $\begin{array}{l}\text { B High } \\
\mathrm{M}_{\mathrm{B}}>\mathrm{M}_{\mathrm{C}}\end{array}$ \\
\hline \multirow[t]{2}{*}{ PERSONAL RELATION } & A and B Friends & FEQP & FBLOW & FBHIGH \\
\hline & Anonymous & $A E Q P$ & ABLOW & ABHIGH \\
\hline
\end{tabular}

Our simple set-up makes it easy to focus on the precise issues that we want to study. We can separately analyze the behavior of players A, B and C and we can study 
the impact of productivities on behavior. First, we are able to study how player A's assignment decision is influenced by whether she personally knows player B.

Second, we can study how player B's decision is influenced by whether he has been chosen by an $\mathrm{A}$ that knows him. In studying players $\mathrm{A}$ and $\mathrm{B}$ in the friends treatment one has to take into account precisely that they know each other, so that, one could say, that the experimental interaction will continue after the experiment itself. In particular, the two friends may be able to share payoffs once the experiment is over. We will get back to this when discussing the results.

Third, we can study the reaction of the $C$ player to the existence of a personal connection between A and B. For all three cases we will be able to see how the influence of personal relations is affected by the productivity differences between B and C. Note that the behavior of players A and B pertain to the direct effects of nepotism, whereas it is in C's behavior where we may find indirect effects of nepotism.

\section{1 The Direct Effects of Nepotism}

The first issue is whether A players will tend to give the larger share of the pie to Bs that are friends. This tendency is what we refer to as nepotism. Altruism has been argued to be one of the main motives behind the direct effect of nepotism (Chami, 1999). Most people care more about family members or friends than for others and try to help them in the organization. Of course, nepotism may also be influenced by the strategic element of expecting to get more back from a friend than from a stranger. Both forces can go together since it is possible that the altruism is mutual.

Note, however, that it is not obvious what to expect. A could suspect that a $\mathrm{C}$ who is favored vis-à-vis a B friend could be especially generous. In addition, the decision could be affected by the difference in productivities. When the friend is the more productive of the two employees simple nepotism should bias the A player even 
more towards giving the larger share to $\mathrm{B}$. Of course, it is also conceivable that more general fairness motivations may guide A's behavior in the opposite direction to compensate the C player for his low productivity. It is not easily foreseeable how these factors will interact. However, minimal groups’ experiments (see Yamagishi et al. 1998 for a survey) show that agents send more money to in-group partners because they expect more reciprocity from the group members. Hence, this literature suggests that discrimination arises as a consequence of expected reciprocity. At this point we posit what we call the nepotism-discrimination hypothesis.

Hypothesis 1: (Nepotism-Discrimination). Principals in the friends' treatment will give the higher share to their friend, independently of productivity.

The second part of the direct effect of nepotism has to do with whether B will react to being favored in a way that is favorable to $\mathrm{A}$. In the experimental literature in economics there is considerable evidence of reciprocal behavior in situations like the one we study (e. g. Berg et al., 1995, etc), but not on whether this is affected by the existence of personal relations. We propose that social distance will affect reciprocal behavior.

Hypothesis 2: (Social distance decreases reciprocal behavior). Friends that obtain the higher share will give back more (in percentage) than anonymous players.

Note that the data could be consistent with only one of the hypotheses. If hypothesis 1 were upheld by the data, but hypothesis 2 not, this could be described as "thankless friends" not reciprocating the good treatment they receive. If hypothesis 2 were consistent with the data, but not hypothesis 1 , then managers would be getting something for nothing from their friends. Both these possibilities did not appear very likely a priori, given the ample evidence for reciprocal giving in games like the one we study here. 


\subsection{The Indirect Effect of Nepotism}

The idea of workers reacting negatively to nepotism in family firms suggested, by Schultz et al. (2001) and Gomez-Mejia et al. (2001) can be supported by several theories. Intentionality arguments suggest that if an agent perceives that he is being treated unfairly, this may prompt negative reactions (Rabin, 1993). ${ }^{5}$ The perception of unfair treatment can have several origins. Equity theory (Adams, 1965), for example, claims that agents value what they obtain with respect to what they contribute. This means that agents that perceive that they deserve more than they obtain will become angry.

Social identification can also provide a basis for this negative reaction to discrimination based on the membership to social groups. When identification is not possible because one person is in a disadvantageous social position, resentment may emerge and cooperation will suffer (Tajfel and Turner, 1986). Milton and Westphal (2005) find evidence of this behavior in work groups. In more general terms, 'embeddedness' (Granovetter, 1985) may be an important factor regulating motivation in job situations. Employees with on the job embeddedness will be highly motivated, whereas employees with low on the job embeddedness will have low motivation (Lee et al. 2004). All these ideas led us to expect a negative reaction to discrimination, as captured in hypothesis 3.

Hypothesis 3: (Discrimination leads to negative reactions). Anonymous agents, when they are less favored in the friends' treatment will give back less than in the anonymous treatment when they are less favored.

It is not self-evident how the differences in productivities will impact on behavior. However, the discussions in Gomez-Mejia et al. (2001) and Miller and

\footnotetext{
${ }^{5}$ There is experimental evidence that negative reactions to unfair treatments exist. See, for example, Brandts and Solà (2001).
} 
LeBreton-Miller (2006) suggest that the reaction of the anonymous player will be more negative when the manager's friend is less able than the other employee.

\section{Experimental Procedures}

Our experimental sessions took place at the Universitat Autònoma de Barcelona between April and October 2005. The sessions were hand-run and involved two large class-rooms, which we will refer to as the $\mathrm{A}$ and the $\mathrm{B} / \mathrm{C}$ room. To recruit participants we posted announcements at different locations on campus, in which we asked interested subjects to sign up in a particular office. We posted separate announcements to recruit subjects for the two rooms. The announcements corresponding to the two different rooms were posted in different buildings of the university in an attempt to minimize prior contact between subjects in the two rooms. At the moment of signing up participants were told in which room to gather for the experiment.

There were small but important differences between the anonymous vs. friends sessions, both with respect to what the announcements said and to how the sign-up process was conducted. For the anonymous treatments the announcements for the two rooms were identical. For the friends treatments the announcements for the A room asked for participants that wanted to take part in the experiment in pairs, while the announcements for the $\mathrm{B} / \mathrm{C}$ room were just like those for the anonymous treatments and did not make any reference to pairs.

When signing-up in the office for the anonymous treatment participants simply wrote their name on a sheet either for the A room or for the $\mathrm{B} / \mathrm{C}$ room. We asked a certain number of subjects to gather in the B/C room and asked double that number of subjects to gather in another classroom, the A room.

In the friends treatments there was a difference between signing up for the A or the $\mathrm{B} / \mathrm{C}$ room. Signing-up for the B/C room took place in exactly the same way as for 
the anonymous treatments. In contrast when signing-up for the A room subjects had to do it in pairs of people who personally knew each other. More specifically, pairs had to write their names at the same time on the inscription sheet for the A room.

For both treatments, the subjects who gathered in the B/C classroom were automatically assigned the role of C. For the subjects that initially gathered in the A classroom we used a random procedure to determine who would have the A and who the B role. For the anonymous treatment subjects simply drew lottery ticket which assigned half of them to the A role and the other half to the B role. For the friends' treatment the assignment of the A and B roles took place as follows. For each pair of subjects that had signed up together for the session we separately determined randomly who would be A and who would be B.

Subjects that had been assigned the Player A role stayed in the A room, whereas the $\mathrm{B}$ players where guided to the $\mathrm{B} / \mathrm{C}$ classroom. While in the $\mathrm{A}$ room the $\mathrm{A}$ and $\mathrm{B}$ roles were being assigned, in the $\mathrm{B} / \mathrm{C}$ classroom subjects with the role of player $\mathrm{C}$ had been randomly seated in order on the right side of the room. Once the B players arrived there they were seated on the left side of the classroom. In the anonymous treatment they were randomly assigned to seats. In the friends treatment the B players were seated in an order that facilitated keeping track of the pairings with the A players.

Then instructions were read aloud, simultaneously in both rooms. After we had finished reading the instructions and answered questions, we distributed decision sheets to subjects. ${ }^{6}$ Again, the friends treatments involved a particular feature: the decision sheet of each A (B) player showed the name of the B (A) player they were paired with. In the anonymous treatments the decision sheets simply showed the identification 
number of the other two people in the trio. This identification numbers could not be tracked by participants to any other individual in the session.

The A players moved first; they marked their decision - whether to give $6 €$ to $\mathrm{B}$ and $4 €$ to $C$ or vice versa - on their decision sheet. We then marked the decision on the corresponding decision sheets of the $\mathrm{B}$ and $\mathrm{C}$ players in the $\mathrm{B} / \mathrm{C}$ room. Then the $\mathrm{B}$ and $\mathrm{C}$ players made their decisions and these were communicated to the corresponding $\mathrm{A}$ players. That was the end of the experimental session; the decisions were one-shot in character.

\section{Results}

Table 2 presents the proportions in which players B in our experiment obtain the higher share in the different treatments. The pattern is remarkably simple: for all three anonymity cells there is a small bias towards $\mathrm{B}$, perhaps just caused by the fact that $\mathrm{B}$ precedes $\mathrm{C}$ in the alphabet. In contrast, in all three friends' cells there is a similar large bias towards B.

Table 2. Proportions of $B$ getting the higher share

\begin{tabular}{|c|c|c|c|c|c|c||}
\hline & FEQP & AEQP & FBLOW & ABLOW & FBHIGH & ABHIGH \\
\hline B & 15 & 12 & 23 & 12 & 26 & 16 \\
\hline TOTAL & 17 & 21 & 25 & 22 & 29 & 29 \\
\hline PROP. & 0.882 & 0.571 & 0.92 & 0.545 & 0.8965 & 0.5517 \\
\hline
\end{tabular}

This impression is confirmed by a Chi-square test which compares the differences in proportions between the three cases involving friends and the three involving anonymous B players; the p-values for the three pair-wise Fischer exact tests are .038, 
.004 and .003 . In short, with respect to hypothesis 1 we find that nepotism exists on the side of player A and is the same irrespective of the productivity of the friend. ${ }^{7}$

Tables 3 presents the mean returns that player A obtains from player $\mathrm{C}$ and Player B in those cases in which Player C (who in the treatments with friends is the anonymous player) gets the low share and Player B gets the high share. With this data we can discuss hypothesis 2 (Social distance decreases reciprocal behavior) and hypothesis 3 (Discrimination leads to negative reactions).

\section{Table 3: Mean returns from Player $C$ getting the low share, from Player $B$ getting the high share, and total return.}

\begin{tabular}{||c|c|c|c|c||}
\hline \multirow{3}{*}{ FEQP } & & RET. C LOW & RET. B HIGH & TOTAL RET. \\
\cline { 2 - 5 } & ABS. & 1.66 & 7.8 & 9 \\
\hline \multirow{3}{*}{ AEQP } & ABS. & 0.13 & 4.43 & 0.3 \\
\cline { 2 - 5 } & PROP. & 1.9047 & 0.2380 & 0.1904 \\
\hline \multirow{3}{*}{ FBLOW } & ABS. & 0.1587 & 6.1521 & 8.444 \\
\cline { 2 - 6 } & PROP. & 0.1637 & 0.4101 & 0.2801 \\
\hline \multirow{3}{*}{ ABLOW } & ABS. & 1.666 & 3.409 & 4.511 \\
\cline { 2 - 6 } & PROP. & 0.111 & 0.1919 & 0.1458 \\
\hline \multirow{2}{*}{ FBHIGH } & ABS. & 0.7884 & 7.7115 & 8.4827 \\
\cline { 2 - 6 } & PROP. & 0.0876 & 0.3672 & 0.2853 \\
\hline \multirow{2}{*}{ ABHIGH } & ABS. & 0.4718 & 0.0312 & 3.8755 \\
\cline { 2 - 6 } & PROP. & 0.0524 & 0.1313 \\
\hline
\end{tabular}

Hypothesis 2 states that friends will give back more (in percentage) than anonymous players. We observe that the returns from player B are systematically higher in the friends' treatments than in the anonymous treatments. Like the behavior of the A 
players, the pattern is quite independent of productivity differences. In treatment FEQP this average return is $43 \%$, whereas in AEQP it is $23.8 \%$. Using the Wilcoxon rank-sum test, this difference is strongly significant $(\mathrm{p}=0.0002)$. This result appears also in treatments FBLOW and ABLOW. In FBLOW the average return is $41.01 \%$ and in ABLOW the return from player B is $19.19 \%$, an again strongly significant difference ( $p=0.0023$ ). Finally, in FBHIGH the return from player B is $36.72 \%$, while in ABHIGH is $19.19 \%$ a significant different at $\mathrm{p}=0.024$. Hence, we conclude that hypothesis 2 is confirmed.

Players A and B that knew each other could conceivably share their money payoffs after the experiment; in a way this just reflects how things are in the situations that we are trying to represent. However, we think that payoff-sharing can not explain away the fact that B players that are friends give back more than strangers. In other words we don't believe that after the experiment the B players in the friends treatments asked the corresponding A players to pay them back what these As had obtained during the experiment in excess of what the As in the anonymous treatments had obtained. Perhaps the B players were asked by their A friends to pay them the rest up to the $50 \%$ sharing, but our impression is that this did not happen. The B players got away with keeping around $60 \%$ of the amount to be shared. In general, subjects accepted the framing of the situation into which we had put them.

We now turn to the returns from players of type $C$ when they get the low share. Hypothesis 3 stated that players of type C would return a lower amount in those treatments where she obtains the low share in a group of friends than in the anonymous treatment. Our results show that this is not so and, again, this fact is not affected by productivity differences. In FEQP the return is $13 \%$, whereas in AEQP it is $15.87 \%$, consistently with this idea, but this difference in not significant at any conventional 
significance level. In treatment FBLOW the mean return from player C is $16.37 \%$, while in ABLOW is $11.11 \%$; the difference is not significantly different. Finally, in FBHIGH the mean return from player $\mathrm{C}$ is $8.76 \%$ and $5.24 \%$ in ABHIGH. Once more, this difference is not significant. Hence hypothesis 3 is clearly rejected in our design. Surprisingly, players of type $\mathrm{C}$ do not appear to be bothered by the fact that the other player, a friend of player $\mathrm{A}$, gets the high share, even in situations where the friend is a low productivity agent. ${ }^{8}$

We can now make some additional remarks about the results. Notice first that, as an implication of the above results, the total return - shown in the last column of table 3 - is significantly higher for treatments where friends play, and that this occurs regardless of the productivities. In FEQP the total return to player $\mathrm{A}$ is $30 \%$ versus $20.63 \%$ in treatment AEQP (Wilcoxon rank-sum, $\mathrm{p}=0.011$ ). In treatment FBLOW the total return amounts to $28.01 \%$ of the resources, almost twice as in ABLOW, $14.58 \%$ (Wilcoxon rank-sum, $\mathrm{p}=0.0007)$. Finally, total return in treatment FBHIGH is $28.53 \%$ versus 13.13\% in ABHIGH (Wilcoxon rank-sum, $\mathrm{p}=0.0007$ ). We will get back to this result at the end of the next section.

\section{Summary and conclusions}

Previous experiments have studied environments in which a truster has to assign different degrees of distributive power to one or several trustees, who stand in competition to each other. Most of these studies do no analyze whether the circumstances under which trustees are assigned to more or less important tasks matter. An important behavioral issue may, hence, have been left aside, since people's

8 Overall, we observe that getting the low share seems the most important factor affecting the level of payback by employees, whereas being in a group with two friends (that share the biggest amount) does not matter. Moreover, player $\mathrm{C}$ behavior does not appear to be strongly influenced by the ratio of productivities between herself and player $\mathrm{B}$. 
motivation in organizational settings may be affected by the circumstances under which the assignment to different tasks took place. In the case we study the relevant circumstances under which task assignment takes place are the existence of personal relations between the truster and one of the trustees. Our focus is on the impact on trustees' behavior of the fact that competition for the higher level of responsibility between the trustees and the existence of personal relations may interact.

We find that, first, given the opportunity to discriminate in a trust relationship between a friend and an anonymous player, our subjects discriminate. This discrimination occurs independently of the exogenously determined ability of the friend with respect to the anonymous player to return trust. Second, we find that friends return systematically more than players in anonymous settings facing the same conditions, again with no clear effects due to the different productivities induced in treatments. Third, anonymous players that interact in a game with two friends and obtain the smaller share of the pie (and in this sense are discriminated) do not react lowering their return to the principal with respect to analogous situations in a purely anonymous game. Fourth, this result is also independent of whether the friend is more or less productive than the third player. Fifth, the manager's total earnings are higher in the case where he interacts with B being a friend than when B is an anonymous player.

With respect to the first and second result what is surprising is their interaction with the fourth result. In the connection between As and Bs who know each other productivity differences play no important role. Managers favor friends and friends give back more than anonymous partners, regardless of relative productivities.

The third result, the rejection of our hypothesis 3, is surprising by itself. A number of ideas can be used to try to rationalize the result. Relative deprivation is defined as the individual's sense of deprivation in comparison with other groups or 
individuals. Hence, an important question is what groups or individuals are used in this comparison (see Akerlof, 1982, 1997). An example would be the documented satisfaction levels of women with respect to men, despite different retributions and labor conditions. Women expect lower salaries because they live in a chauvinist society; hence they experience similar satisfaction levels with lower wages than men. Social identity may to help us understand what groups are used in comparisons.

Tropp \& Wright (1999) argue that an individual's sense of deprivation may depend on whether the comparison is perceived to be inter-group or intra-group and the level of identification of the person with respect to his own group. They find that in selfoutgroup comparisons, highly identified individuals report more deprivation than individuals low in identification” In this sense, Miller (2001) points out that people believe that they deserve more respect from other individuals pertaining to the same group.

Moreover, a key issue here may be legitimacy. Tyler (2006) argues that when differences between groups are legitimate, people will not perceive bad outcomes as a reflection of discrimination. On the contrary, if differences between groups are perceived as illegitimate, they may generate anger. This effect has been observed by psychologists in experimental research (Brown and Ross, 1978; among others). Applied to the case of family firms it suggests that non family members may interpret that family members have a legitimate status in the family firm and, hence, they accept discrimination.

Our fifth result can be seen as a kind of bottom line of the whole study. From the manager's point of view it is better to be in an experimental firm with friends. In addition, the earnings of the manager are very similar across the three cases with friends 
(FEQP, FBLOW and FBHIGH). To see how this comes about just compare behavior between FBLOW and FBHIGH in table 3. The discriminated $\mathrm{C}$ player in FBHIGH gives back less in absolute terms and in proportions than in FBLOW. At the same time the friend makes a somewhat larger effect when he is unproductive - in FBLOW - than in the other case, leading to the overall effect of no effect.

In our experiment identical material payoffs are to be shared in the absence and in the presence of personal relations between two of the subjects. Only in laboratory experiments can one arrange conditions to be so tightly parallel. Despite the limitations of laboratory experiments we believe that there is considerable value in being able to cleanly identify treatment effects. We favor an approach in which laboratory experiments, field data from naturally occurring situations and other insights are used together to shed light on the phenomena of interest. 


\section{References}

Adams, J.S. 1965. Inequity in social exchange. In Berkowitz (Ed.), Advances in experimental social psychology ( ${ }^{\text {nd }}$. ed.): 267-299. New York: Academic Press.

Akerlof, G. A. 1982. Labor Contracts as partial gift exchange. The Quarterly Journal of Economics, Vol. XCVII (4), 543-569.

Akerlof, G. A. 1997. Social distance and social decisions. Econometrica, Vol. 65 (5), 1005-1027.

Anderson, R. and Reeb, D.M. 2003. Founding family ownership and firm performance: Evidence from the S\&P 500. Journal of Finance 58, 1301-1329.

Bates, T. W., Jandik, T. and Lehn, K. 1998. The Structure of Executive Compensation in Founder-Run Firms, mimeo, University of Pittsburgh.

Berg, J., Dickhaut, J. and McCabe, K. 1995. Trust, reciprocity, and social history. Games and Economic Behavior 10, pp. 122-142.

Bohnet, I. and Frey, B. S. 1999. Social Distance and Other-Regarding Behavior in Dictator Games: Comment. American Economic Review, Vol. 89 (1), 335-339.

Bolton, G. E., and Ockenfels, A. (2000). ERC: A Theory of Equity, Reciprocity and Competition. American Economic Review 90(1),166-93.

Brandts, J., Güth, W. and Stiehler, W. 2006. I want YOU! An experiment studying the selection effect when assigning distributive power. Labour Economics 13, 1-17.

Brandts, J. and C. Solà (2001). Reference Points and Negative Reciprocity in Simple Sequential Games. Games and Economic Behavior 36, 138-157.

Brown, R. and Ross, G. F. 1982. The battle for acceptance: an exploration into the dynamics of intergroup behaviour. In H. Tajfel (ed.) Social identity and intergroup relations, Cambridge: Cambridge University Press. 
Burkart, M., Panuzzi, F., and Schleiffer, A. 2003. Family Firms. The Journal of Finance, vol. LVIII, pp. 2167-2201.

Chami, R. 2001. What is Different about Family Businesses? IMF Working Paper.

Cho, M-H. 1998. Ownership structure, investment, and the corporate value: an empirical analysis. The Journal of Financial Economics 47, 103-121.

Demsetz, H., Villalonga, B. 2001. Ownership structure and corporate performance. Journal of Corporate Finance 7, 209-233.

Fama, E. and Jensen, M. 1983a. Separation of Ownership and Control. Journal of Law and Economics 26, 301-325.

Gomez-Mejia, L. R., Nuñez-Nickel, M. and Gutierrez, I. 2001. The Role of Family Ties in Agency Contracts. Academy of Management Journal, Vol. 44 (1), 81-95.

Granovetter, M. 1985. Economic Action and Social Structure: The Problem of Embeddedness. American Journal of Sociology 91(3).

Greenberg, J. 1990. Organizational justice: Yesterday, Today, and Tomorrow. Journal of Management, vol. 16, No.2, 399-432.

Hoffman, E., McCabe, K., and Smith, V. L. 1996. Social Distance and Other-Regarding Behavior. American Economic Review, Vol. 83 (3), 653-660.

Jensen M.C:, and Meckling, W.H. 1976. Theory of the Firm: Managerial Behavior, Agency Costs and Ownership Structure. Journal of Financial Economics 3, pp. 305-360.

Kang, D. 2000. The impact of family ownership on performance in public organizations: A study of the U.S. Fortune 500, 1982-1994. Harvard Business School Working Paper 00-051.

Kets de Vries, M.F.R. 1993. The Dynamics of Family Controlled Firms : The Good and the Bad News. Organizational Dynamics 21(3), 59-71. 
Kole, S. R. 1997. The Complexity of Compensation Contracts. Journal of Financial Economics, vol. 43, 79-104.

La Porta, R., Lopez-de-Silanes, F., and Shleifer, A. 1999. Corporate Ownership around the World. The Journal of Finance, Vol. LIV, No.2, 471-517.

Lee, T. H., Mitchell, T. R., Sablynski, C. J., Burton, J. P., \& Holtom, B C. 2004. The Effects of Job Embeddedness on Organizational Citizenship, Job Performance, Volitional Absences, and Voluntary Turnover. Academy of Management Journal, Vol. 47, No. 5, 711-722.

Malhotra, D. 2004. Trust and Reciprocity decisions: The differing perspectives of trustors and trusted parties. Organizational Behavior and Human Decision Processes 94, 61-73.

Malhotra, D. and J. K. Murnighan 2002. The Effects of Contracts on Interpersonal Trust. Administrative Science Quarterly, 47, 534-559.

McConaughy, D.L., Walker, M.C., Herderson, G:V:, and Mishra C. S. 1998. Founding Family Controlled Firms: Efficiency and Value. Review of Financial Economics, Vol. 7, No. 1, 1-19.

Miller, D. T. 2001. Disrespect and the Experience of Injustice. Annual Review of Psychology 52: 527-53.

Miller, D., and Le Breton-Miller, I. 2006. Family Governance and Firm Performance: Agency, Stewardship, and Capabilities. Family Business Review, vol. XIX, no. 1, pp. 73-87.

Milton, L. P. and Wesphal, J. D. 2005. Identity Confirmation Networks and Cooperation in Work Groups. Academy of Management Journal, Vol.48, No.2, 191-212. 
Mork, R., Wolfenzon, D., and Yeung, B. 2004. Corporate Governance, Economic Entrenchment and Growth. NBER Working Paper Series.

Mork, R.K., Shleifer, A., and Vishny, R. 1988. Management ownership and market valuation: An empirical analysis. Journal of Financial Economics 20, 293-315.

Pérez-González, F. forthcoming. Inherited Control and Firm Performance. American Economic Review.

Pollak, R. A. 1985. A Transaction Cost Approach to Families and Households. Journal of Economic Literature, vol. XXIII, pp. 581-608.

Rabin, M. 1993. Incorporating Fairness into Game Theory and Economics. American Economic Review 83, 1281-1302.

Schulze, W. S., Lubatkin, M. H., Dino, R. N., and Buchholtz, A. K. 2001. Agency Relationships in Agency Firms: Theory and Evidence. Organization Science vol. 12 (2), pp. 99-116.

Sugden, R. (1984). Reciprocity: The Supply of Public Goods Through Voluntary Contributions. Economic Journal, 94, 772-787.

Tajfel, H. and J. Turner (1986). The Social Identity Theory of Intergroup Behavior. In S. Worchel and G. Austin (Eds.), Psychology of intergroup relations ( $2^{\text {nd }}$ ed., 724), Chicago: Nelson-Hall.

Tropp, L. R. and Wright, S. C. 1999. Ingroup Identification and Relative Deprivation: An Examination across Multiple Social Comparisons. European Journal of Social Psychology, 29, 707-724.

Tyler, T.R. 2006. Psychological Perspectives on Legitimacy and Legitimation. Annual Review of Psychology 57: 375-400.

Van der Hayden, L., Bondel, C. \& Carlock, R. S. 2005. Fair Process: Striving for Justice in Family Business. Family Business Review, vol. XVIII, no.1, 1-21. 
Villalonga, B., and Amit, R. 2004. How Do Family Ownership, Control, and Management Affect Firm Value?. Manuscript.

Weber, R.A., Rottenstreich, Y., Camerer, C. and Knez, M. 2001. The illusion of leadership: Misattribution of cause in coordination games. Organization Science, 12, 582-598.

Yamagishi, T., Jin, N, \& Miller, A.S. 1998. In-group bias and culture of collectivism. Asian Journal of Social Psychology, 1: 315-328. 


\section{APPENDIX 1: THE INSTRUCTIONS}

Note to readers: This instructions and decisions sheets refer to the treatment FBLOW, that is, the treatment where A and B know each other personally and player B has a low productivity factor in comparison to C. We write in italics the appropriate changes for the case of the ABLOW treatment, that is, the treatment where all players are anonymous.

Welcome and thank you for coming today. From now on, we ask you to remain silent. If you have any question, raise your hand and an assistant will come to you.

This session consists of you making decisions that will affect both you and other people participating in this session.

\section{Participation:}

In order to enroll people in this session, we have followed two procedures. In one case we have placed announcements in several buildings of this university asking for voluntary participation in a research project involving decision making. In the other case we placed announcements asking for voluntary participation in a research project involving decision making of two-person groups. (This section is missing in the treatment $A B L O W)$.

\section{Development of the session:}

We have constituted groups of three people (in treatment ABLOW we include: randomly). In each group, two people enrolled together for this session as explained above. Hence, two of the three persons in a group know each other and the other has been selected randomly among the participants enrolled individually. (In treatment $A B L O W$, instead of last sentence read: Nobody will know the identity of the people in her group.)

In each group of three people we have three types of participant. A participant of type A, a participant of type B, and a participant of type C. Participants of type A are in one classroom and participants of type B and C are in another classroom. The participant of type A knows personally one of the other members in her group and she will be able to 
identify her (she knows whether the other is of type B or type C), in the same way that this person will be able to identify participant A. (In treatment ABLOW we substitute the last sentence by: Assignment of types to participants is random)

\section{Participant of type A:}

Participant type A will make only one decision. This participant receives a quantity of $10 €$ and she must decide to whom she wants to assign $4 €$ in the group and to whom she wants to assign $6 €$. Once she has made this decision, the amount of money that she decided to allocate is multiplied. The amount received by participant of type B in her group in multiplied by 2.5 and the amount allocated to participant of type $\mathrm{C}$ is multiplied by 3.75. Therefore, the amounts that participants of type B and C may receive are:

\begin{tabular}{|c|c|c|c|}
\hline & & $\mathrm{B}$ receives & $\mathrm{C}$ receives \\
\hline A sends & $\begin{array}{l}4 € \text { to } B \text { and } 6 € \text { to } \\
\text { C }\end{array}$ & $10 €(10 €=4 € * 2.5)$ & $22,5 €(22,5 €=6 € * 3.75)$ \\
\hline A sends & $\begin{array}{l}6 € \text { to } B \text { and } 4 € \text { to } \\
\text { C }\end{array}$ & $15 €\left(15 €=6 €^{*} 2.5\right)$ & $15 €(15 €=4 € * 3.75)$ \\
\hline
\end{tabular}

Once the participant of type A will have made her decision, this decision will be communicated individually to the members of her group.

\section{Participants of type B and C:}

Participants of type B and C, once the participant of type A in their group has made her own decision, also have to make decisions. The participant of type B will receive either $10 €$ ( $4 €$ assigned by $A$ that are multiplied by 2.5 ) or $15 €$ (6 $€$ assigned by $A$ that are 
multiplied by 2.5). Whatever the amount received, her decision consists in deciding how much of the amount she keeps for herself and how much she decides to give to player A. For the participant of type $C$ the decision is identical. She will receive either $15 €(4 €$ transferred by A which are multiplied by 3.75), or $22.5 €$ (6€ transferred by A multiplied by 3.75). Once the amount received is known, she must decide how much of the amount she keeps for herself and how much she decides to give to player A. Participants of type $\mathrm{B}$ and $\mathrm{C}$ make decisions individually.

\section{Payments:}

When participants of type $\mathrm{B}$ and $\mathrm{C}$ will have made their decisions, these decisions will be communicated to player $\mathrm{A}$ and the session will end. The payments that each of them will receive are the following: A will receive the amount that player B will have decided to give her plus the amount that player $\mathrm{C}$ will have decided to give her. $\mathrm{B}$ and $\mathrm{C}$ will receive the amounts that they have decided to keep for themselves.

\section{End of the session:}

Once all the decisions will have taken place, you will know the amount that you will receive for your participation in the session. You will fill out the receipt you found in your folder and we will pay each of you according to the decisions made.

Once we have paid you, leave the room silently. Thanks for you cooperation.

On the next page you will find a summary of the decisions for each type of participant in each group. Now we will hand out the decision pages on which you will register your decisions. 
Decision by A:

Option 1

Option 2:
$4 €$ to $B$ and $6 €$ to $C$

$6 €$ to $B$ and $4 €$ to $C$

Decision by B:

\begin{tabular}{ll}
\hline If $15 €(=6 € * 2,5)$ & Amount she sends to A (she keeps the difference) \\
\hline If $10 €(=4 € * 2,5)$ & Amount she sends to $A$ (she keeps the difference)
\end{tabular}

Amount received

Decision by C:

If $15 €\left(=4 €^{*} 3,75\right) \quad$ Amount she sends to $A$ (she keeps the difference)

If $22,5 €\left(=6 €^{*} 3,75\right) \quad$ Amount she sends to A (she keeps the difference)

\section{Payments}

Type of participant

Amount in Euros

\begin{tabular}{|c|c|}
\hline A & Amount that $B$ sends her + Amounts that $C$ sends her \\
\hline \multirow{2}{*}{ B } & 15 - amount she sends to $A$ \\
\hline & 10 - amount she sends to $A$ \\
\hline \multirow{2}{*}{$\mathrm{C}$} & 15 - amount she sends to $A$ \\
\hline & If she receives 22,5: $\quad 22,5$ - amount she sends to $\mathrm{A}$ \\
\hline
\end{tabular}




\section{DECISION SHEET}

\section{TYPE OF PARTICIPANT: A}

The participant of Type B in your group is: [The name of the person she has signed up with appears here]

(In the anonymous treatments the previous sentence is missing)

Your decision consists of selecting one the options below. Please, mark clearly your option.

\section{Decision by A:}

\section{Option 1: \\ $4 €$ to $B$ and $6 €$ to $C$}

\section{\begin{tabular}{l|l} 
Option 2: & $6 €$ to $B$ and $4 €$ to $C$
\end{tabular}}

In the table below we will write down the decisions made by participants of type B and $\mathrm{C}$ in your group.

\begin{tabular}{|l|l|}
\hline \multicolumn{2}{|c|}{ Decisions from B and C } \\
\hline Amount sent by B: & \\
\hline Amount sent by C: & \\
\hline Total amount: & \\
\hline
\end{tabular}




\section{DECISION SHEET}

TYPE OF PARTICIPANT: $\mathbf{B}$

The participant of Type A in your group is: [The name of the person she has signed up with appears here]

(In the anonymous treatments a participant number appears above)

We will mark the amount sent to you by A. Once you know the amount sent to you by A, and knowing that in your case this amount is multiplied by 2.5 , your decision is how much you want to send to A and how much you want to keep for yourself. Below you can write the amount sent to A.

\section{Decision by B:}

\begin{tabular}{|l|l|l|}
\hline \multicolumn{3}{|c|}{ A SENT YOU 4€ } \\
\hline & Amount to send to A & Amount to keep for yourself \\
\hline You have 10€ $\left(4 €^{*} 2,5\right)$ & & \\
\hline
\end{tabular}

\begin{tabular}{|l|l|l|}
\hline \multicolumn{3}{|c|}{ A SENT YOU 6€ } \\
\hline & Amount to send to A & Amount to keep for yourself \\
\hline You have 15€(6€*2,5) & & \\
\hline
\end{tabular}




\section{DECISION SHEET}

TYPE OF PARTICIPANT: $\mathbf{C}$

Participants of type A and B in your group know each other personally.

(In the anonymous treatments a participant number appears above)

We will mark the amount sent to you by A. Once you know the amount sent to you by A, and knowing that in your case this amount is multiplied by 3.75 , your decision is how much you want to send to A and how much you want to keep for yourself. Below you can write the amount sent to A.

Decision by C:

\begin{tabular}{|l|c|c|}
\hline \multicolumn{3}{|c|}{ A SENT YOU 4€ } \\
\hline & Amount to send to A & Amount to keep for yourself \\
\hline You have 15€ (4€*3,75) & & \\
\hline
\end{tabular}

\begin{tabular}{|c|c|c|}
\hline \multicolumn{2}{|c|}{ A SENT YOU 6€ } \\
\hline & Amount to send to A & Amount to keep for yourself \\
\hline You have 22,5€ & & \\
$\left(6 €^{*} 3,75\right)$ & & \\
\hline
\end{tabular}


APPENDIX 2: THE RAW DATA

Treatment FEQ

Treatment AEQ

\begin{tabular}{|c|c|c|c|c|c|c|c|c|c|}
\hline B & $\mathrm{C}$ & Ret. B & Ret. C & Higher & B & $\mathrm{C}$ & Ret. B & Ret. C & Higher \\
\hline 12 & 18 & 2 & 3 & C & 18 & 12 & 0 & 2 & B \\
\hline 18 & 12 & 8 & 6 & B & 18 & 12 & 3 & 2 & B \\
\hline 18 & 12 & 7 & 0 & B & 18 & 12 & 5 & 2 & B \\
\hline 18 & 12 & 6 & 4 & B & 12 & 18 & 1 & 3 & C \\
\hline 18 & 12 & 8 & 0 & B & 18 & 12 & 0 & 0 & B \\
\hline 18 & 12 & 6 & 1 & B & 12 & 18 & 4 & 3 & C \\
\hline 18 & 12 & 6 & 2 & B & 18 & 12 & 6 & 0 & B \\
\hline 18 & 12 & 6 & 2 & B & 18 & 12 & 2 & 6 & B \\
\hline 18 & 12 & 8 & 0 & B & 12 & 18 & 0 & 8 & C \\
\hline 18 & 12 & 9 & 1 & B & 12 & 18 & 0 & 6 & C \\
\hline 12 & 18 & 4 & 2 & C & 12 & 18 & 8 & 3 & C \\
\hline 18 & 12 & 9 & 0 & B & 18 & 12 & 1 & 1 & B \\
\hline 18 & 12 & 9 & 2 & B & 18 & 12 & 2 & 0 & B \\
\hline 18 & 12 & 9 & 2 & B & 12 & 18 & 3 & 6 & $\mathrm{C}$ \\
\hline 18 & 12 & 8 & 2 & B & 12 & 18 & 1 & 8 & C \\
\hline 18 & 12 & 9 & 1 & B & 18 & 12 & 4 & 2 & B \\
\hline \multirow[t]{5}{*}{18} & 12 & 9 & 2 & B & 12 & 18 & 2 & 8 & C \\
\hline & & & & & 18 & 12 & 8 & 2 & B \\
\hline & & & & & 12 & 18 & 4 & 6 & $\mathrm{C}$ \\
\hline & & & & & 18 & 12 & 0 & 0 & B \\
\hline & & & & & 18 & 12 & 8 & 0 & B \\
\hline
\end{tabular}




\begin{tabular}{|c|c|c|c|c|c|c|c|c|c|}
\hline B & $\mathrm{C}$ & Ret. B & Ret. C & Higher & B & $\mathrm{C}$ & Ret. B & Ret. C & Higher \\
\hline 15 & 15 & 5 & 0 & B & 15 & 15 & 5 & 0 & B \\
\hline 15 & 15 & 6 & 7 & B & 10 & 22.5 & 0.5 & 2.5 & C \\
\hline 15 & 15 & 7.5 & 1 & B & 15 & 15 & 2 & 0 & B \\
\hline 15 & 15 & 7 & 5 & B & 10 & 22.5 & 0 & 0 & C \\
\hline 15 & 15 & 7.5 & 5 & B & 10 & 22.5 & 0 & 3.5 & C \\
\hline 15 & 15 & 7.5 & 2 & B & 15 & 15 & 1 & 2 & B \\
\hline 15 & 15 & 7 & 0 & B & 15 & 15 & 6 & 5 & B \\
\hline 15 & 15 & 7.5 & 3 & B & 15 & 15 & 4 & 0 & B \\
\hline 15 & 15 & 7.5 & 0 & B & 15 & 15 & 0 & 0 & B \\
\hline 15 & 15 & 7.5 & 0 & B & 10 & 22.5 & 0 & 4 & $\mathrm{C}$ \\
\hline 10 & 22.5 & 5 & 1.5 & $\mathrm{C}$ & 15 & 15 & 5 & 0 & B \\
\hline 15 & 15 & 5 & 0 & B & 10 & 22.5 & 0 & 0 & $\mathrm{C}$ \\
\hline 15 & 15 & 8 & 10 & B & 15 & 15 & 0 & 5 & B \\
\hline 15 & 15 & 5 & 4 & B & 10 & 22.5 & 1.75 & 7.5 & C \\
\hline 15 & 15 & 5 & 0 & B & 15 & 15 & 4 & 0 & B \\
\hline 10 & 22.5 & 0.1 & 6.5 & $\mathrm{C}$ & 10 & 22.5 & 0 & 0 & C \\
\hline 15 & 15 & 5 & 0.5 & B & 10 & 22.5 & 0 & 2.5 & C \\
\hline 15 & 15 & 5 & 0 & B & 15 & 15 & 2 & 5 & B \\
\hline 15 & 15 & 7.5 & 4 & B & 10 & 22.5 & 0 & 10 & C \\
\hline 15 & 15 & 6 & 0 & B & 10 & 22.5 & 2 & 5 & C \\
\hline 15 & 15 & 5 & 0 & B & 15 & 15 & 5 & 3 & B \\
\hline 15 & 15 & 0 & 5 & B & 15 & 15 & 6 & 0 & B \\
\hline 15 & 15 & 0 & 0 & B & & & & & \\
\hline 15 & 15 & 15 & 5 & B & & & & & \\
\hline 15 & 15 & 5 & 5 & B & & & & & \\
\hline
\end{tabular}




\begin{tabular}{|c|c|c|c|c|c|c|c|c|c|}
\hline B & $\mathrm{C}$ & Ret. B & Ret. C & Higher & B & $\mathrm{C}$ & Ret. B & Ret. C & Higher \\
\hline 21 & 9 & 11 & 0 & B & 14 & 13.5 & 4 & 0 & $\mathrm{C}$ \\
\hline 21 & 9 & 0 & 3 & B & 21 & 9 & 1 & 0 & B \\
\hline 21 & 9 & 0 & 3 & B & 14 & 13.5 & 0 & 1.5 & C \\
\hline 21 & 9 & 10.5 & 0 & B & 21 & 9 & 1 & 1 & B \\
\hline 21 & 9 & 0 & 0.5 & B & 21 & 9 & 0 & 0 & B \\
\hline 21 & 9 & 10.5 & 3 & B & 21 & 9 & 1 & 0 & B \\
\hline 21 & 9 & 10 & 3 & B & 21 & 9 & 10 & 0 & B \\
\hline 21 & 9 & 0 & 0 & B & 14 & 13.5 & 0 & 0 & $\mathrm{C}$ \\
\hline 21 & 9 & 10 & 0 & B & 14 & 13.5 & 3 & 3.5 & $\mathrm{C}$ \\
\hline 21 & 9 & 10.5 & 0 & B & 14 & 13.5 & 0 & 0 & $\mathrm{C}$ \\
\hline 21 & 9 & 10 & 0 & B & 14 & 13.5 & 2 & 3.5 & $\mathrm{C}$ \\
\hline 14 & 13.5 & 10 & 3.5 & $\mathrm{C}$ & 14 & 13.5 & 0 & 3.5 & $\mathrm{C}$ \\
\hline 21 & 9 & 12 & 0 & B & 21 & 9 & 1 & 1 & B \\
\hline 21 & 9 & 0 & 1 & B & 14 & 13.5 & 0 & 4.5 & $\mathrm{C}$ \\
\hline 21 & 9 & 10.5 & 1 & B & 21 & 9 & 0 & 0.5 & B \\
\hline 21 & 9 & 10.5 & 2 & B & 14 & 13.5 & 0 & 1.5 & $\mathrm{C}$ \\
\hline 21 & 9 & 10 & 0 & B & 21 & 9 & 6 & 0 & B \\
\hline 21 & 9 & 10.5 & 1 & B & 14 & 13.5 & 2 & 1.5 & $\mathrm{C}$ \\
\hline 21 & 9 & 10.5 & 1 & B & 21 & 9 & 0 & 2 & B \\
\hline 21 & 9 & 8.5 & 0 & B & 21 & 9 & 7 & 0 & B \\
\hline 21 & 9 & 7 & 0 & B & 21 & 9 & 7 & 0 & B \\
\hline 21 & 9 & 21 & 0 & B & 14 & 13.5 & 0.5 & 0.5 & $\mathrm{C}$ \\
\hline 21 & 9 & 5 & 0 & B & 21 & 9 & 1 & 0 & B \\
\hline 21 & 9 & 5 & 2 & B & 21 & 9 & 7 & 0 & B \\
\hline 14 & 13.5 & 8 & 0 & $\mathrm{C}$ & 14 & 13.5 & 1 & 3.34 & C \\
\hline 21 & 9 & 10.5 & 0 & B & 21 & 9 & 7 & 0.05 & B \\
\hline 21 & 9 & 7 & 0 & B & 21 & 9 & 5 & 2 & B \\
\hline 21 & 9 & 0 & 0 & B & 14 & 13.5 & 1 & 3.5 & $\mathrm{C}$ \\
\hline 14 & 13.5 & 0 & 3.5 & $\mathrm{C}$ & 21 & 9 & 10.5 & 1 & B \\
\hline
\end{tabular}

